Lelly Qodariah, Melinda Rahmawati - Festival Peh Cun: Pesta Musim Panas Mayarakat Tionghoa di Kota Tangerang

\title{
FESTIVAL PEH CUN : PESTA MUSIM PANAS MASYARAKAT TIONGHOA DI KOTA TANGERANG
}

\section{Lelly Qodariah}

Universitas Muhammadiyah Prof.Dr.HAMKA, Jakarta, Indonesia Email: lelly_qodariah@uhamka.ac.id

\section{Melinda Rahmawati}

Universitas Muhammadiyah Prof.Dr.HAMKA, Jakarta, Indonesia Email: melinda@uhamka.ac.id

\section{Article history:}

Submitted Sept 28, 2020

Revised Oct 28, 2020

Accepted Jan 19, 2021

Published June 11, 2021

\begin{abstract}
The purpose of this research is to know a series of activities in Peh Cun Festival and the meaning of each procession carried out. The festival which is celebrated by Chinese Society in Tangerang has its own cultural and historical values. The Method used in this research is Explanative Qualitative Method with a generative approach that gives a detailed identification of a series of Peh Cun Festival celebrated by the Chinese Society and the meaning of the activity. This research used literature study analysis by comparing and studying several literacies such as textbooks, scientific journals and others related to Peh Cun Festival and the meaning of each process carried out. The results of this research are describes of a series of activities and meanings from the holding of the Peh Cun Festival. The conclusion of this research is The Peh Cun Festival is a summer festival celebrated by the Chinese Society with its own significance preserved as cultural heritage.
\end{abstract}

Key Words : Chinese society; cultural heritage; Peh Cun festival; summer party

\begin{abstract}
ABSTRAK
Tujuan dari penelitian ini untuk mengetahui rangkaian kegiatan dalam Festival Peh Cun dan makna dari setiap prosesi yang dilakukan. Festival yang dirayakan masyarakat Tionghoa di Kota Tangerang memiliki nilai budaya dan historis tersendiri. Metode yang digunakan dalam penelitian ini ialah metode kualitatif eksplanatif dengan pendekatan generatif yang memberi identifikasi rinci mengenai rangkaian acara Festival Peh Cun yang dirayakan masyarakat Tionghoa Kota Tangerang dan makna dalam kegiatan tersebut. Penelitian ini menggunakan analisis studi pustaka dengan membandingkan dan mengkaji beberapa literasi seperti buku teks, jurnal ilmiah dan lainnya yang berkaitan dengan Festival Peh Cun dan makna dari setiap prosesi yang dilakukan. Hasil dari penelitian ini mendeskripsikan rangkaian kegiatan dan makna ritual Festival Peh Cun.
\end{abstract}


Lelly Qodariah, Melinda Rahmawati - Festival Peh Cun: Pesta Musim Panas Mayarakat Tionghoa di Kota Tangerang

Simpulan dari penelitian ini ialah Festival Peh Cun merupakan festival musim panas yang dirayakan masyarakat Tionghoa dengan memiliki makna tersendiri yang dilestarikan sebagai warisan budaya.

Kata Kunci : masyarakat Tionghoa; warisan budaya; festival Peh Cun; pesta musim panas

\section{PENDAHULUAN}

Budaya Tionghoa memang telah lama mengakar sejak aktifnya jalur perdagangan laut dan jalur sutera di Asia. Salah satu budaya Tionghoa yakni berdagang dan berkelana yang menjadikan masyarakat Tionghoa tersebar diseluruh dunia. Dalam catatan sejarah, Nusantara telah menjadi tempat persinggahan tokoh-tokoh besar Tionghoa seperti I-Tsing dan Laksamana Cheng Ho. Khususnya di Pulau Jawa, umumnya masyarakat Tionghoa berasal dari para saudagar dan anak buah kapal dari Laksamana Cheng Ho yang memilih menetap di Nusantara dan enggan kembali ke tanah leluhurnya. Mereka menetap dan menikah dengan penduduk setempat, hingga terjadilah akulturasi budaya melalui jalur perkawinan ini. Hingga kini, masyarakat Tionghoa tumbuh dan berkembang sebagai masyarakat minoritas yang turut mewarnai integrasi nasional dan wajah masyarakat multikultural Indonesia.

Pada masa pemerintahan Hindia Belanda, pemerintah kolonial menetapkan kelompok sosial-masyarakat yang menimbulkan disorganisasi dalam kelompok masyarakat. kelompok pertama yakni golongan Masyarakat Keturunan Belanda atau Eropa. Kelompok kedua yakni golongan Masyarakat Tionghoa dan Arab, kelompok ketiga yakni golongan Masyarakat Bumiputera (Pribumi). Kelompok sosial-masyarakat yang dilakukan oleh pemerintah hindia belanda tentu untuk mempermudah kontrol sosial dalam masyarakat di Hindia Timur. Masyarakat Tionghoa dan Arab pada masa itu mendapatkan ekslusivitas baik secara kelompok maupun individu sebagai mitra dagang pemerintah. Mereka menjadi pihak yang cenderung mendukung kebijakan pemerintah dan memiliki jalinan kerja sama yang terbentuk sangat erat. Sehingga Ekslusivitas yang terbentuk dalam Masyarakat Tionghoa dan Arab menjadi bagian yang tidak lepas dari sejarah yang mewarnai perubahan sosial dalam skala yang besar dan kompleks dalam masyarakat Indonesia (Jones, 2015).

Salah satu bentuk ekslusivitas masyarakat yang dibuat oleh pemerintah kolonial ialah dibentuknya perkumpulan masyarakat Tionghoa peranakan di 
Lelly Qodariah, Melinda Rahmawati - Festival Peh Cun: Pesta Musim Panas Mayarakat Tionghoa di Kota Tangerang

daerah Tangerang yang sering dikenal dengan istilah Cina Benteng. Masyarakat Tionghoa cina benteng ini dari masa pemerintahan kolonial hingga kini telah membaur dengan masyarakat sekitar. Meskipun pembauran yang terjadi berawal dari sebuah eklusivitas masyarakat yang dibuat oleh pemerintah kolonial sebagai bagian dari kelas sosial yang dibentuk. Namun, nyatanya kini budaya Tionghoa tersebut telah berakulturasi dan melekat sebagai salah satu identitas masyarakat kota tangerang. Melalui Perkumpulan Boen Tek Bio, masyarakat Tionghoa menjaga dan melestarikan tradisi-tradisi yang diturunkan oleh leluhur mereka. Di dalam Klenteng Boen Tek Bio yang berlokasi di Jl. Bhakti No. 14 Kota Tangerang masih terdapat sisa-sisa peninggalan dari para leluhur mereka, seperti lonceng klenteng yang dikirim langsung dari tiongkok yang dibuktikan dengan cetakan angka yang menuliskan tahun 1835 dan diidentifikasi sebagai lonceng yang dibuat oleh perusahaan pengecoran Ban Coan Lou (Ahmadibo, 2018e). Serta masih banyak lagi peninggalan-peninggalan dari para leluhur masyarakat cina benteng yang masih terawat dan mengandung makna tesendiri yang patut kita lestarikan bersama.

Terlepas dari eklusivitas yang terbentuk, terdapat sebuah catatan buruk yang pernah dialami oleh masyaakat Tionghoa peranakan di kota Batavia yakni Pembantaian Masyarakat Tionghoa pada tahun 1740, akibatnya banyak masyarakat Tionghoa peranakan dan Tionghoa totok berpindah ke pinggir kota Batavia (Al-Ayubi, 2016; Karina, 2018).

Festival Peh Cun sendiri sebagai pesta musim panas memiliki nilai budaya dan filosofis tersendiri di setiap rangkaian kegiatannya. Festival Peh Cun yang puncak acaranya adalah perlombaan perahu naga memiliki historis tersendiri berkaitan dengan peristiwa yang terjadi pada salah satu penasehat kerajaan di tanah tiongkok pada masa Dinasti Zhou. Sesuai dengan tradisi dalam konfusianisme, maka tradisi Peh Cun ini dirayakan untuk mengenang peristiwa tersebut dan waktu yang tepat untuk berdoa kepada Tian (Tuhan) dan memohon kesehatan, keberkahan, pemanggil hujan, dan keberuntungan sepanjang tahun (Ahmadibo, 2018e).

Dari penelitian-penelitian sebelumnya yang membahas terkait keberadaan Festival yang serupa dengan Peh Cun membahas tentang simbolsimbol ritual, maka artikel ini berfokus pada makna ritual dari rangkaian Festical Peh Cun. Simbol dan harmonisasi yang ada di Kota Tangerang jika dilihat pada fungsional dan realitas sosial yang ada. Hal itu menekankan pada 
Lelly Qodariah, Melinda Rahmawati - Festival Peh Cun: Pesta Musim Panas Mayarakat Tionghoa di Kota Tangerang

pembahasan pada keharmonisan kerukunan beragama pada realitas kehidupan bermasyarakat.

\section{TEORI DAN METODE PENELITIAN}

Teori yang digunakan dalam penelitian ini adalah teori sejarah. Sejatinya, Tionghoa peranakan ialah mereka (orang Tionghoa asli) yang menikahi orang pribumi setempat sehingga terjadi perkawinan silang yang menghasilkan keturunan campuran antara Tionghoa dan pribumi setempat (Melati, 2018; Reza et al., 2014). Perkawinan silang ini terjadi umumnya karena memang masyarakat Tionghoa yang datang mayoritas ingin menetap di Nusantara dan membangun jejaring perdagangan dikawasan Nusantara ini. Dari perkawinan silang tersebutlah terbentuk sebuah kelompok turunan dari masyarakat Tionghoa yakni masyarakat Tionghoa peranakan. Pembeda antara masyarakat Tionghoa asli (Tionghoa totok) dengan Tionghoa peranakan dapat dilihat dari warna kulit, dialek, dan akulturasi budaya yang tampak khususnya dari segi kesenian. Masyarakat Tionghoa totok tentu masih memeganng teguh tradisi dan kepercayaan milik leluhur mereka, sedangkan masyarakat Tionghoa peranakan sudah mulai melakukan berbagai penyesuaian dengan budaya tempat mereka tinggal saat ini. Penyesuaian yang dilakukan dapat dilihat dari ragam kesenian yang ditampilkan, pola hidup masyarakat, mata pencaharian yang tidak hanya berdagang, dan kepercayaan masyarakat yang tidak semuanya menganut kepercayaan Kong $\mathrm{Hu} \mathrm{Cu}$. Ragam akulturasi ini yang mewarnai multikulturalisme yang ada ditengah masyarakat Indonesia.

Masyarakat Tionghoa peranakan secara umum merupakan masyarakat yang religius. Mereka mayoritas memeluk agama Buddha. Umumnya didalam sebuah klenteng mereka terdapat tiga ruangan yang penuh dengan patung para dewa dan satu kamar khusus untuk altar leluhur. Khususnya pada etnis cina benteng, mereka memanfaatkan aliran sungai cisadane untuk pengairan lahan pertanian mereka sehingga mereka hidup sebagai petani, peternak, nelayan, bahkan pengayuh becak (Al Ayubi, Sholahuddin., Kurniawan, 2009; Inisiasi dan Komunitas - Lintas Budaya Indonesia, 2009). Etnis Tionghoa peranakan juga pada masa orde baru sempat mendapat tindak diskriminasi ditengah masyarakat sebagai akibat dari tragedi G 30 S/PKI. Namun, sejak reformasi diskriminasi tersebut mulai dihilangkan dan Kong $\mathrm{Hu} \mathrm{Cu}$ di akui sebagai agama resmi yang ada di Indonesia. 
Metode penelitian yang digunakan adalah metode kualitatif eksplanatif. Metode Kualitatif dengan analisis eksplanatif menitikberatkan pada penjelasan mengenai faktor penyebab terjadinya sebuah peristiwa atau fenomena (Purwanto, Erwan Agus., Sulistyastuti, 2017). Analisis eksplanatif yang digunakan pula dengan pandangan generatif, dimaksudkan bahwa penjelasan mengenai penyebab terjadinya sebuah peristiwa dilihat dari struktur kejadian dan mekanisme terjadinya peristiwa tersebut. Metode ini digunakan untuk menjelaskan mengenai rangkaian acara festival Peh Cun dan makna dari setiap rangkaian acara yang dilakukan. Festsival Peh Cun sebagai salah satu festival tradisi yang selalu dirayakan tentu memiliki makna tersendiri khususnya bagi masyarakat Tionghoa peranakan di Kota Tangerang. Makna tersebut yang hingga kini dilestarikan dan menjadi nilai budaya warisan leluhur antar generasi oleh masyarakat Tionghoa peranakan di Kota Tangerang. Data yang digunakan dalam penelitian berupa data sekunder yang bersifat kepustakaan. Data tersebut disadur dari buku - buku literasi yang secara khusus membahas mengenai dan buku - buku literasi yang membahas mengenai awal kehadiran masyarakat Tionghoa peranakan di Kota Tangerang hingga makna dari setiap rangkaian acara dalam Festival Peh Cun yang diadakan di Sungai Cisadane, serta kumpulan jurnal ilmiah yang dipublikasikan dan diunduh melalui mesin pencari google cendekia.

Penguasaan metode kualitatif eksplanatif dengan pandangan generatif berguna untuk memberi identifikasi berupa penjelasan secara rinci mengenai masyarakat Tionghoa peranakan yang tinggal di Kota Tangerang, tradisi yang masih dirawat dan dilestarikan oleh mereka, dan rangkaian acara dari festival Peh Cun beserta makna dari masing-masing acara yang diselenggarakan. Seperti yang kita ketahui bahwa masyarakat Tionghoa peranakan yang tinggal di Kota Tangerang atau yang sering disebut dengan "cina benteng" merupakan salah satu kelompok masyarakat Tionghoa yang telah membaur dengan masyarakat setempat dan menciptakan akulturasi dengan budaya masyarakat sekitar. Beberapa tradisi leluhur masyarakat Tionghoa masih dilestarikan dan dijaga sebagai nilai budaya warisan para leluhur dari generasi ke generasi. Salah satu tradisi leluhur yang masih dilestarikan ialah festival Peh Cun yang dirayakan setiap tahun pada tanggal 5 bulan 5 penanggalan Kong $\mathrm{Hu} \mathrm{Cu}$. Festival Peh Cun sebagai pesta musim panas yang dirayakan oleh masyarakat cina benteng dan kini menjadi festival tahunan yang dirayakan oleh seluruh warga Kota Tangerang. Festival ini juga memiliki makna tersendiri pada setiap 
Lelly Qodariah, Melinda Rahmawati - Festival Peh Cun: Pesta Musim Panas Mayarakat Tionghoa di Kota Tangerang

rangkaian acaranya. Keunikan makna tersebut yang menarik untuk ditelusuri lebih lanjut dan secara bersama dilestarikan sebagai warisan budaya.

\section{HASIL DAN PEMBAHASAN}

\section{Masyarakat Tionghoa Di Kota Tangerang dan Tradisi yang Masih Terjaga}

Harmonisasi kehidupan masyarakat Tionghoa peranakan khususnya etnis cina benteng di Kota Tangerang menjadi salah satu contoh akulturasi budaya Tionghoa di Indonesia dan menjadi pusat perkampungan bagi etnis Tionghoa peranakan selain di daerah Pecinan, Glodok, Teluk Gong, dan Sekitarnya.

Kota Tangerang sendiri memiliki sejarah yang mnejadikan dirinya menjadi sebuah kota benteng pada masa VOC. Tertulis dalam Dag Register, tahun 1684 melalui perjanjian antara Bupati Tangerang I dan VOC. Tangerang lepas dari kekuasaan Kesultanan Banten dan resmi berada dibawah kendali pemerintah kompeni. Pada 1705 dituliskan dalam arsip Gewone Resolutie Van hat Casteel Batavia, dibangunlah sebuah benteng yang diukur dari muara Sungai Tangerang (Sulistomo, 2018). Kedatangan masyarakat Tionghoa di Teluk Naga dan memulai akulturasi budaya dengan masyarakat setempat. Masyarakat Tionghoa banyak yang melakukan pernikahan dengan masyarakat setempat sehingga terjadi akulturasi budaya melalui perkawinan. Kota Tangerang sendiri juga menjadi saksi dari pembantaian etnis Tionghoa oleh VOC pada tahun 1741, banyak etnis Tionghoa yang awalnya tinggal di Batavia mengungsi dan menyelamatkan diri ke Kota Tangerang dan pinggiran kota Batavia. Kini, Kota Tangerang tidak hanya terkenal dengan "Penyangga Ibukota" namun juga sebagai salah satu kota penting yang menyimpan banyak sejarah dan kebudayaan khususnya kebudayaan Tionghoa peranakan.

Sejak kedatangan rombongan yang pimpin oleh Chen Cie lung (salah satu rombongan yang ikut bersama rombongan Laksamana Cheng Ho) pada abad ke-6 di Teluk Naga, mereka melakukan akulturasi dan asimilasi budaya dengan masyarakat melayu-betawi hingga menjadi etnis cina benteng yang kita kenal sekarang ini (Santosa, 2012; Sulistomo, 2018). Para rombongan tersebut secara masif tinggal menetap disepanjang aliran sungai cisadane sebagai petani, pedagang, dan lainnya lalu melakukan pernikahan dengan gadis setempat hingga terbentuklah keturunan cina benteng yang berkulit gelap dan hidup sederhana. Akulturasi budaya sangat kental terlihat ketika kita menghadiri 
perayaan-perayaan yang diselenggarakan oleh masyarakat cina benteng. Seperti kostum penari, kostum sehari-hari, alat musik gambang kromong, dan dan arsitektur bangunan juga menjadi bukti adanya aklturasi budaya dikalangan etnis cina benteng tangerang.

Asimilasi budaya juga nampak di tengah warna-warni budaya cina benteng ini. Mereka yang berasal dari Keturunan Hokkian, ketika tinggal dan menetap bersama dengan masyarakat sunda khususnya terjadi perubahan dialek dan pola kebiasaan (Ham, 2009; Inisiasi dan Komunitas - Lintas Budaya Indonesia, 2009). Keturunan Cina Benteng yang sekarang tidak lagi secara penuh dapat berbicara dalam dialek Hokkian seperti leluhur mereka dan mereka juga tidak lagi memiliki kepandaian bela diri seperti wushu, kung fu, dan sejenisnya. Mereka bahkan hampir tidak mengenal lagi sejarah leluhur mereka. Mereka hanya mengetahui bahwa mereka telah tinggal dan menetap secara turun temurun di Kota Tangerang. Dialek mereka sudah berubah menjadi dialek sunda pinggiran dengan sedikit membawa dialek betawi. Sebabnya etnis cina benteng ini dapat dikenali dari ciri fisik, penganut kepercayaan konfuisme, dan budaya yang masih dilestarikan.

Hadirnya etnis Cina Benteng turut mewarnai instrumen multikultural yang ada di kota Tangerang ini. Kekayaan multikulturalnya dapat kita lihat dari dilaksanakannya beragam perayaan-perayaan hari besar bagi masyarakat Tionghoa khususnya cina benteng seperti Imlek, Cap Go Meh, Peh Cun, dan perayaan-perayaan lainnya (Arif, 2014). Perayaan yang umumnya diselenggarakan secara meriah tentu menjadi wadah untuk terbentuknya sebuah multikultural ditengah masyarakat khususnya yang terjadi di Kota Tangerang. Masyarakat cina benteng yang tetap melestarikan dan memegang adat istiadat yang diajarkan oleh leluhur mereka tetap menghormati dan berbaur dengan budaya yang berkembang ditengah masyarakat sekitarnya. Dapat dikatakan bahwa diantara etnis Tionghoa yang menetap di Indonesia, masyarakat cina bentenglah yang pengakulturasian dan asimilasi budaya yang cukup banyak dibandingkan dengan etnis Tionghoa lainnya.

\section{Festival Peh Cun Sebagai Pesta Musim Panas Tahunan di Kota Tangerang}

Peh Cun sendiri berasal dari tutur kata dalam bahasa hokkian yakni Peh Liong Cun dengan arti perlombaan perahu naga atau Duan Wu Jie yang dirayakan setiap tanggal 5 bulan 5 dalam kalender lunar (Agung, 2018; 
Lelly Qodariah, Melinda Rahmawati - Festival Peh Cun: Pesta Musim Panas Mayarakat Tionghoa di Kota Tangerang

Danandjaja, 2007; Melati, 2018). Perayaan Peh Cun sebagai perayaan yang sangat istimewa karena melalui perayaan tersebutlah mereka dapat terhubung dengan para leluhur mereka. Dengan ciri khasnya yakni perlombaan perahu naga dan makan $b a^{\prime}$ cang, perayaan ini menjadi sangat meriah dan selalu dirayakan oleh masyarakat Tionghoa dimanapun mereka berada. Khususnya di Kota Tangerang, Perayaan Peh Cun tidak hanya dirayakan oleh masyarakat cina benteng saja. Kini perayaan tersebut telah menjadi festival tahunan yang diselenggarakan oleh Pemda Kota Tangerang dan menjadi salah satu acara yang diminati para wisatawan. Perayaan ini dikenal sebagai pesta musim panas karena umumnya tanggal 5 bulan 5 dalam kalender lunar jatuh pada musim kemarau dalam kalender masehi.

Festival Peh Cun sendiri memiliki sejarah tersendiri, tepatnya tanggal 5 bulan 5 diyakini sebagai hari tragis bunuh dirinya seorang penasehat pada masa Dinasti Couw bernama Khut Goan (Cu Yuan). Keruntuhan yang telah diprediksi jauh sebelumnya namun tidak dihiraukan oleh kaisar hingga hal yang diprediksipun terjadi. Khut Goan ( $\mathrm{Cu}$ Yuan) merasa sangat menyesal karena tidak dapat menyelamatkan negerihya hingga akhirnya ia mengakhiri hidupnya di hulu Sungai Bek-Lo. Seluruh penduduk dan prajurit kerajaan mencari jasadnya namun tidak menemukannya, akhirnya penduduk melempar sebuah makanan yang terbuat dari beras dan daging (kalau kini disebut dengan bakcang) agar jasad Khut Goan ( $\mathrm{Cu}$ Yuan) tidak dimakan hewan predator sungai tersebut (Melati, 2018; Rosyadi, 2010). Dari kisah inilah lahir perayaan Peh Cun dengan ciri khasnya yakni perlombaan perahu naga dan memakan $b a^{\prime}$ cang. Bak-cang yang dibuatpun tidak hanya dikonsumsi melainkan digunakan pula dalam upacara perayaannya. Mulai dari digantung di teras rumah hingga turut dilarung di sungai dengan kepercayaan bahwa naga air tidak akan memakan jasad sang penasehat karena tersayat oleh daun bambu yang menjadi pembungkus dari $b a^{\prime} c a n g$ itu sendiri.

Festival Peh Cun tidak saja dikenal sebagai ajang perlombaan perahu naga saja, namun juga terdapat rangakaian upacara yang harus dilaksanakan seperti memandikan sebuah perahu naga yang dikeramatkan, berdoa sebelum memulai rangkaian acara dan ditengah rangkaian acara, melemparkan ba'cang ke sungai, mendirikan telur, memetik tanaman obat dan mandi tepat di siang hari, dan sebagai puncak dari rangkaiannya ialah perlombaan perahu naga yang dimeriahkan oleh seluruh masyarakat khususnya di Kota Tangeran (Nasir, 2019). Rangkaian upacara ini diselenggarakan sesuai dengan tradisi 
peribadatan milik masyarakat Tionghoa. Terdapat tiga ajaran yang disebut Tridharma. Dalam Thridharma terdapat ajaran Dao (Buddha), ajarann $R u$ (konghucu), dan ajaran Tian (Tuhan Yang Maha Esa). Setiap manusia harus mengikuti kehendak dari Tian-Dao (Tuhan Yang Maha Esa), lalu manusia harus berperilaku sebagai jati diri (Xing) nya, dan akhirnya adanya pemujaan terhadap arwah yang ada di alam semesta ini. Pemujaan inilah yang lebih berkaitan erat pada makna dari rangkaian Festival Peh Cun.

Festival Peh Cun ini juga dimeriahkan oleh barongsai dan iringan musik gambang kromong. Peserta saling berlomba memperebutkan batang bambu berdaun yang diikat dengan sapu tangan atau kain cita. Sebelum puncak acara, masyarakat mengadakan prosesi mandi ditengah hari dengan tujuan agar memperoleh rezeki berlimpah, panjang umur, dan mudah mendapatkan jodoh. Selama perayaan juga masyarakat Tionghoa peranakan juga membuat sebuah kue yang dikenal dengan kue ba'cang. Mitosnya ialah, terdapat seorang pejabat istana yang bermimpi mengenai perdana menteri yang bunuh diri. Jika ia ingin menemukan jasad dari perdana menteri tersebut maka ia harus melalkukan tari naga di air dengan membawa sebuah ba'cang (sejenis kue basah terbuat dari beras yang dikukus dan dibungkus dengan daun bambu). Diyakini bahwa perdana menteri tersebut jasadnya hilang dimakan oleh naga air, jika $b a^{\prime} c a n g$ tersebut dilempar ke sungai atau laut dan termakan oleh naga air maka naga air akan tersayat oleh daun $b a^{\prime}$ cang hingga naga tersebut mengeluarkan tubuh perdana menteri tersebut (Shahab, 2000). Kepercayaan ini yang menjadikan perayaan Festival Peh Cun menjadi khidmat dan meriah. Karena tidak hanya sebuah perayaan biasa, melainkan juga memiliki sejarah panjang dari leluhur masyarakat Tionghoa itu sendiri.

Dengan mitos tersebut lahirlah tradisi Peh Liong Cun atau kini dikenal dengan Peh Cun. Dengan lambang khasnya yakni ikon naga, menjadikan perayaan ini kental dengan nuansa Tionghoa dengan akulturasi budaya masyarakat banten yang turut mewarnainya. Hingga akhirnya perayaan ini tidak hanya dirayakan oleh masyarakat Tionghoa peranakan di tangerang, tetapi juga dirayakan oleh seluruh masyarakat Kota Tangerang (Iqbal, 2019; Kustdeja, Sugiri., Sudikno, Antariksa., Salura, 2013; Zuliansyah, 2019). Khususnya pada perayaan Festival Peh Cun, Masyarakat Kota Tangerang dan sekitarnya turut antusias meramaikannya. Keseruan banyak terjadi di berbagai rangkaian kegiatan dalam perayaan ini seperti pada saat prosesi mendirikan 
Lelly Qodariah, Melinda Rahmawati - Festival Peh Cun: Pesta Musim Panas Mayarakat Tionghoa di Kota Tangerang

telur, mandi di siang hari, melempar bebek ke sungai cisadane, dan pada prosesi puncak nya yakni lomba perahu naga di Sungai Cisadane.

Festival Peh Cun atau secara umum kini dikenal dengan Festival Cisadane menjadi salah satu agenda tahunan yang dilaksanakan oleh Pemerintah Daerah Kota Tangerang, Banten (Siregar \& Sembada, 2019). Dengan antusiasme masyarakat yang tinggi, maka Pemerintah Daerah Kota Tangerang menjadikan perayaan Peh Cun ini tidak hanya sebagai perayaan ibadah saja melainkan menjadi agenda festival tahunan yang diselenggarakan di Kota Tangerang. Tidak hanya itu, Festival Peh Cun yang kini dikenal dengan festival Cisadane juga menjadi salah satu ikon dari Kota Tangerang. Dengan demikian akulturasi budaya masyarakat cina benteng yang berada di Kota Tangerang sangat terasa. Budaya khas yang dimiliki oleh masyarakat cina benteng telah nyata berbaur dengan masyarakat sekitarnya dan menjadi budaya milik bersama. Keharmonisan ini yang patut kita syukuri sebagai kekayaan budaya bangsa Indonesia.

\section{Makna dari Setiap Rangkaian Acara Dalam Festival Peh Cun}

Sebagai sebuah perayaan yang telah diwariskan sejak nenek moyang terdahulu, Perayaan Peh Cun ini memiliki serangkaian acara yang harus dilaksanakan dan dari setiap rangkaian acara tersebut memiliki makna tersendiri. Perayaan pehcun tidak hanya menjadi momentum acara ibadah bagi penganut Kong $\mathrm{Hu} \mathrm{Cu}$, namun juga menjadi sebuah festival budaya yang diagendakan setiap tahun dan dapat mengundang banyak wisatawan yang datang untuk memeriahkan festival tersebut. Perayaan yang kental dengan nilai historis ini, tentu diwariskan secara turun-temurun antar generasi agar mereka selalu ingat dengan leluhurnya dan menjaga tradisi tersebut dari masa ke masa. Pertalian yang terbangun menjadi semakin kokoh antar generasi walaupun tetap harus terjadi asimilasi sebagai bentuk penyesuaian dengan kondisi saat ini. Asimilasi yang terbentuk tidak semata - mata menurunkan nilai-nilai budaya yang telah melekat secara mengakar dan menurunkan nilai historisnya. Dengan demikian Perayaan Peh Cun ini memiliki makna yang patut diketahui bersama untuk dilestarikan dan dijaga sebagai bentuk keragaman budaya bangsa Indonesia. Makna dari setiap rangkaian acara dalam Perayaan Festival Peh Cun yang diadakan oleh Masyarakat Cina Benteng di Kota Tangerang sebagai berikut: 
Lelly Qodariah, Melinda Rahmawati - Festival Peh Cun: Pesta Musim Panas Mayarakat Tionghoa di Kota Tangerang

Pertama, diadakan Pembacaan Doa (Keng) Sembahyang Samkay, dan Sembahyang Twan Yang. Sembahyang ini memang sesuai dengan ajaran Tridharma yakni pemujaan terhadap arwah yang ada di alam semesta ini dan ajaran Tian. Ajaran Tian mengajarkan bahwa manusia harus mengikuti kehendak dari Tian-Dao (Tuhan Yang Maha Esa), maka segala aktivitas dimulai dengan sebuah ritual sembahyang (Ahmadibo, 2018c). Samkay sendiri yang berarti sesaji mengandung makna persembahan pada tiga penguasa yakni kepada penguasa langit, penguasa bumi, dan penguasa air. Persembahan yang dilakukan guna mengarapkan keberkahan rejeki (Tian Guan), penghapusan kesalahan (Di Guan), dan terhindar dari bencana (Shi Guan). Adapun dalam versi lain mengatakan bahwa ketiga hal tadi merupakan konsep kosmologi Tionghoa da nada yang beranggapan bahwa ketiga hal tersebut merupakan dewa purba. Sembahyang ini dilakukan tepat tengah malam pada agenda pertama dalam perayaan Peh Cun ini. Lalu pada siang harinya diadakan sembahyang Twan Yang. Sembahyang Twan Yang ini yang diadakan tepat pada tanggal 5 bulan 5 penanggalan Kong $\mathrm{Hu} \mathrm{Cu}$ pada siang hari. Sembahyang Twan Yang ini bermakna bahwa manusia harus menjaga lingkungannya dan melestarikan alam agar tetap seimbang dan lestari.

Kedua, memandikan perahu papak merah Peh Cun. Perahu yang kini berada di Pendopo Peh Cun - Tanah Go Cap, Karawaci. Telah ada sejak tahun 1900-an Yang dibawa langsung oleh Kapitan Cina Oey Giok Koeun. sebuah cerita yang menjadikan perahu ini memiliki mitos ialah perahu tersebut sempat patah dibagian tengahnya saat mengikuti lomba perahu naga di sungai cisadane. Akan tetapi perahu tersebut tidak tenggelam dan dapat menyelesaikan pertandingan tersebut hingga akhir. Sebabnya perahu tersebut kini di keramatkan oleh masyarakat cina benteng dan menjadi prosesi ritual wajib yang dilakukan dalam Perayaan Peh Cun di Kota Tangerang (Ahmadibo, 2018d). Prosesi ini juga dilakukan sebagai simbol penghormatan kepada Qu Yuan yang telah berjasa walaupun dirinya harus berakhir tragis. Perahu yang dimandikan ialah perahu papak merah dan hijau dengan arti warna bahwa manusia memiliki kehidupan dan mengalami kematian (warna hijau secara umum digunakan untuk menandakan kematian). Kedua perahu ini dimandikan dengan air kembang dan cara memandikannya dengan diusapkan pada badan perahu menggunakan kain merah. Konon berdasarkan kepercayaan masyarakat sekitar, air bekas memandikan perahu papak tersebut dapat membawa berkah layaknya air yang mengalir. Prosesi ini juga masih 
Lelly Qodariah, Melinda Rahmawati - Festival Peh Cun: Pesta Musim Panas Mayarakat Tionghoa di Kota Tangerang

dilakukan pada malam hari 1 hari setelah diadakannya sembahyang samkay. Setelah prosesi memandikan perahu ini pula diadakan acara hiburan seperti penampilan gambang kromong.

Ketiga, melempar $b a^{\prime} c a n g$ dan menggantung padi di teras rumah. Kue $b a^{\prime}$ cang yang telah dikenal oleh masyarakat Tionghoa sejak lama sekali memiliki arti sendiri sebagai bentuk penghormatan pada mendiang Khut Goan. Masyarakat Tionghoa kuno percaya bahwa jasad mendiang Khut Goan dimakan oleh naga air. Untuk melindungi jasad mendiang Khut Goan, ba'cang tersebut dilemparkan ke sungai dan ketika termakan oleh naga air maka akan tersayat oleh daun pembungkus $b a^{\prime}$ cang tersebut (Danandjaja, 2007; Shahab, 2000). Tida hanya itu, $b a^{\prime}$ cang juga memiliki arti tersendiri yang membawa harapan. ba'cang yang terdiri dari empat sudut mengandung arti; sudut pertama diharapkan agar suami-isteri saling mencinta satu sama lain, sudut kedua harapan doa baik untuk keluarga agar damai, sejahtera dan sehat., sudut ketiga harapan agar keberkahan dan rejeki selalu mengalir, dan terakhir pada sudut keempat harapan agar setiap usaha yang dijalankan mengalami peningkatan dan berjalan sukses.

Keempat, memanen tanaman obat-obatan, setelah melakukan sembahyang Twan Yang masyarakat cina benteng biasanya memanen tanaman obat. Pada waktu ini dipercaya bahwa tanaman tersebut sedang dalam kondisi baik dan khasiat dari tanaman obat tersebut dapat dimanfaatkan secara sempurna (Ahmadibo, 2018f; Rosyadi, 2010). Para ahli obat-obatan Tionghoa percaya bahwa pada hari perayaan Peh Cun terjadi persatuan antara hawa bumi dan langit sehingga seluruh yang hidup di bumi terkena hawa tersebut. masyarakat Tionghoa khususnya mayarakat cina benteng tentu memanen tanaman obat yang mereka tanam pada hari itu guna mendapatkan khasiat yang maksimal dari tanaman obat tersebut.

Kelima, mendirikan telur, setelah memanen tanaman obat masyarakat cina benteng dan masyarakat sekitar melakukan tradisi mendirikan telur tepat pada bagian ujungnya. Kepercayaan yang ada pada masyarakat Tionghoa ialah jika telur yang didirikan berdiri secara sempurna, maka akan mendapat berkat dari langit. Pada saat ini, gaya tarik-menarik antara gravitasi bumi dan matahari sedang menguat yang menyebabkan telur tersebut dapat berdiri pada ujungnya (Ahmadibo, 2018a; Rosyadi, 2010). Pada prosesi ini, banyak warga sekitar maupun wisatawan lokal yang memang sengaja datang untuk ikut memeriahkan acara ini. Acara mendirikan telur ini menjadi sangat meriah 
Lelly Qodariah, Melinda Rahmawati - Festival Peh Cun: Pesta Musim Panas Mayarakat Tionghoa di Kota Tangerang

karena banyak orang yang akan mencoba untuk mendirikan telur pada acara tersebut. meskipun ada yang gagal, secara umum banyak telur yang sukses berdiri pada acara ini. Pada prosesi ini terlihat pembauran masyarakat cina benteng dengan masyarakat sekitar. Suasana yang terasa ialah tradisi ini seakan-akan tidak hanya milik masyarakat cina benteng saja melainkan milik seluruh masyarakat Kota Tangerang. Pada prosesi ini lah yang menjadi daya tarik dari destinasi wisata Kota Tangerang dalam Perayaan Peh Cun.

Keenam, mandi di siang hari, prosesi ini dikenal dengan sebutan mandi $u$ shi dan tentu dipercaya untuk membebaskan diri dari penyakit dan membuang sial. Prosesi ini berlangsung selama 1-2 jam di aliran sungai. Prosesi ini sangat meriah karena tidak hanya seluruh masyarakat cina benteng saja yang melakukannya, melainkan masyarakat sekitar yang tinggal di Pasar Lama, Kota Tangerang juga turut serta untuk menambah meriah rangkaian acara ini (Dhe Regar, 2020; Tracy, 2017). Prosesi ini yang mengundang banyak perhatian masyarakat sehingga acara ini semakin penuh dengan keceriaan. Seluruh masyarakat baik masyarakat cina benteng maupun masyarakat sekitar dengan serunya bermain air pada prosesi ini, tidak ada yang memandang perbedaan suku, etnis, atau apapun. Semua orang saling memeriahkan rangkaian acara ini dengan penuh suka cita. Pada prosesi ini lah yang menjadi daya tarik dari destinasi wisata Kota Tangerang dalam Perayaan Peh Cun.

Ketujuh, melempar bebek di Sungai Cisadane, prosesi ini dikenal dengan Ci Swa juga memiliki arti membuang sial dengan di lambangkan oleh dilemparnya bebek-bebek tersebut ke Sungai Cisadane (Ahmadibo, 2018b). seketika setelah bebek-bebek tersebut menjadi rebutan para pemuda dan suasana berubah menjadi lomba menangkap bebek di Sungai Cisadane. Setiap tahun, panitia penyelenggara dari Perkumpulan Boen Tek Bio menyiapkan ratusan ekor bebek yang siap dilepas ke sungai dan dijadikan rebuta oleh dua kelompok pemuda. acara ini dibuka oleh Walikota Kota Tangerang dan Pimpinan Perkumpulan Boen Tek Bio dengan prosesi tabor bunga di sekitar aliran Sungai Cisadane ini. Prosesi tabur bunga ini sebagai pengharapan agar rangkaian acara ini berjalan lancar. Setelah acara tabur bunga selesai barulah bebek-bebek tersebut dilempar dan menjadi rebutan dari para pemuda. keseruan pun datang dari para warga yang ikut memberikan sorak-sorai pada para pemuda yang berusaha menangkap bebek-bebek tersebut. sebagai akhir dari acara ini, bebek-bebek yang telah ditangkap boleh dibawa pulang dan dinikmati bersama. 
Lelly Qodariah, Melinda Rahmawati - Festival Peh Cun: Pesta Musim Panas Mayarakat Tionghoa di Kota Tangerang

Kedelapan, lomba perahu naga di Sungai Cisadane, rangkaian acara ini yang menjadi puncak dari perayaan Peh Cun di Sungai Cisadane, Kota Tangerang. Acara ini lah yang menjadi daya tarik pariwisata di Kota Tangerang. Perlombaan perahu naga inilah yang menjadi ikon utama dari Perayaan Peh Cun dan menggambarkan makna sesungguhnya dari Perayaan Peh Cun ini (Ahmadibo, 2018f). Perlombaan yang diikuti oleh empat kelompok dengan masing-masing perahu naga berjumlah 10 orang, mereka berlomba untuk mencapai ujung lintasan yang berjarak 500 meter. Hadiah yang diperebutkan tentunya sangat menarik, bahkan perlombaannyapun penuh sorak sorai dari para penonton yang menyaksikan perlombaan ini. Perahu naga yang menjadi gambaran mengenang pencarian jasad dari Khut Goan yang hilang di Sungai Bek Lo tidak saja berjalan khidmat, namun juga meriah. Pemenang dalam lomba perahu naga pada perayaan Peh Cun ini tidak hanya mendapat peluang untuk mengikuti lomba perahu naga tingkat nasional bahkan internasional.

Perayaan Festival Peh Cun atau Festival Cisadane tidak saja menjadi ritual keagamaan dan kepercayaan milik masyarakat cina benteng saja, melainkan kini telah menjadi milik seluruh masyarakat Kota Tangerang. Dengan tetap menjaga makna-maknya yang terkandung dalam setiap rangkaian acara, perayaan Festival Peh Cun ini menjadi daya tarik wisata dari Kota Tangerang ini. Sebuah Perayaan yang memiliki sejarah leluhur sangat kental dan budaya yang sangat terasa menyebabkan perayaan ini kaya dengan nilai budaya yang patut untuk dilestarikan bersama oleh generasi selanjutnya.

\section{SIMPULAN}

Festival Peh Cun yang rutin dirayakan oleh masyarakat cina benteng di Kota Tangerang pada tanggal 5 bulan 5 dalam kalender Kong $\mathrm{Hu} \mathrm{Cu}$, sesuai dengan nama aslinya yakni Duan Wu Jie menjadikan festival ini kental dengan nilai-nilai budaya warisan para leluhur dari masyarakat cina benteng. Festival yang selalu jatuh pada musim panas menjadikan perayaannya semakin semarak dan dapat dijadikan sebagai daya tarik pariwisata di Kota Tangerang. Masing-masing rangkaian acara dalam Perayaan Festival Peh Cun ini memiliki nilai-nilai dan filosofi serta pengharapan tersendiri seperti agar mendapatkan keberkahan dari Tuhan, terhindar dari musibah dan penyakit, membuang semua pengaruh-pengaruh negatif dalam diri, mengetahui salah satu sejarah yang pernah terjadi pada para leluhur, dan masih banyak nilai-nilai khususnya 
nilai budaya yang melekat dan patut dilestarikan secara bersama. Walaupun kini perayaan Festival Peh Cun juga telah menjadi festival tahunan yang diselenggarakan bersama oleh Pemerintah Kota Tangerang dan menjadi daya tarik wisatawan untuk berwisata ke Kota Penyanggah Ibukota ini. Masyarakat Cina Benteng yang telah bermukim jauh sebelum kedatangan bangsa eropa ke tanah Nusantara, dan telah mengakulturasikan diri dengan budaya setempat membuat Perayaan Festival Peh Cun ini tidak hanya menjadi ciri dari masyarakat cina benteng saja. Namun Festival ini telah menjadi milik seluruh masyarakat Kota Tangerang. Serta, pelestarian nilai-nilai budaya yang terkandung juga menjadi tanggung jawab bersama agar generasi selanjutnya tetap mengetahui sejarah leluhurnya dan nilai-nilai budaya yang diwariskannya.

\section{DAFTAR PUSTAKA}

Agung. (2018). Klenteng Boen Tek Bio. Indonesia Kaya. https://indonesiakaya.com/pustaka-indonesia/klenteng-boen-tek-bio/

Ahmadibo. (2018a). Kepercayaan telur berdiri dalam perayaan Peh Cun. Indonesia Kaya. https://indonesiakaya.com/ pustaka-indonesia/kepercayaan-telurberdiri-dalam-perayaan-pehcun/

Ahmadibo. (2018b). Melempar bebek membuang sial. Indonesia Kaya. https://indonesiakaya.com/pustaka-indonesia/melempar-bebekmembuang-sial/

Ahmadibo. (2018c). Melestarikan lingkungan dengan sembahyang Twan Yang. Indonesia Kaya. https:/ / indonesiakaya.com/pustakaindonesia/melestarikan-lingkungan-dengan-sembahyang-twan-yang/

Ahmadibo. (2018d). Prosesi memandikan perahu di hari raya Peh Cun. Indonesia Kaya. https://indonesiakaya.com/pustaka-indonesia/prosesimemandikan-perahu-di-hari-raya-pehcun/

Ahmadibo. (2018e). Semarak perayaan Pehcun di Sungai Cisadane. Indonesia Kaya. https://indonesiakaya.com/pustaka-indonesia/semarak-perayaanpehcun-di-sungai-cisadane/

Ahmadibo. (2018f). Tradisi Perahu Naga di Har Raya Peh Cun. Indonesia Kaya. https://indonesiakaya.com/pustaka-indonesia/tradisi-perahu-naga-dihari-raya-peh-cun/

Al-Ayubi, S. (2016). Cina Benteng : pembauran dalam masyarakat majemuk di Banten. Jurnal Kalam, 10(2), 317-358.

Al Ayubi, Sholahuddin., Kurniawan, A. F. (2009). Cina benteng: antara pluralitas, 
Lelly Qodariah, Melinda Rahmawati - Festival Peh Cun: Pesta Musim Panas Mayarakat Tionghoa di Kota Tangerang

kesukubangsaan, dan kepercayaan. Jakarta: FUD Press.

Arif, M. (2014). Model kerukunan sosial pada masyarakat multikultural Cina Benteng (kajian historis dan sosiologis). Sosio Didaktika, 1(1), 52-63. DOI: 10.15408/sd.v1i1.1212

Danandjaja, J. (2007). Folklor Tionghoa; sebagai terapi penyembuh amnesia terhadap suku bangsa dan budaya Tionghoa. Jakarta: Pustaka Utama Grafiti.

Dhe Regar. (2020). Tradisi "Peh Cun", Festival kebaikan yang dirayakan masyarakat Tionghoa hari ini. Digtara.

https:// www.digtara.com/gaya/budaya/tradisi-peh-cun-festivalkebaikan-yang-dirayakan-masyarakat-tionghoa-hari-ini/

Ham, O. H. (2009). Riwayat Tionghoa peranakan di Jawa. Depok: Komunitas Bambu.

Inisiasi dan Komunitas - Lintas Budaya Indonesia. (2009). Peranakan Tionghoa, sebuah perjalanan. Jakarta: PT. Inisiasi Mediatama dan Komunitas - Lintas Budaya Indonesia.

Iqbal, M. (2019). Tradisi Cina Benteng, perayaan Pehcun persatukan warga Tangerang. IDN Times.

https:// banten.idntimes.com/news/indonesia/muhammad-iqbal15/dari-tradisi-cina-benteng-perayaan-pehcun-persatukan-wargatangerang

Jones, T. (2015). Kebudayaan dan kekuasaan di Indonesia: kebijakan budaya selama abad ke-20 hingga era reformasi (E. R. Terre (ed.)). Jakarta: Yayasan Pustaka Obor Indonesia, KITLV-Jakarta.

Karina, R. L. (2018). Strategi adaptasi masyarakat Cina benteng dalam kehidupan masyarakat multikultural: studi kasus pada masyarakat Cina Benteng di Kota Tangerang. Skripis Fakultas Pendidikan Ilmu Pengetahuan Sosial, Universitas Pendidikan Indoneisa, 1-9.

Kustdeja, Sugiri., Sudikno, Antariksa., Salura, P. (2013). Makna ikon naga, long 龙，龍 elemen utama arsitektur tradisional Tionghoa. Jurnal Sosioteknologi, 30(12), 526-539.

Melati, I. (2018). Perancangan informasi sejarah dan nilai dari tradisi Peh Cun melalui cooperative card game. Skipsi Fakultas Desain Komunikasi Virtual, Universitas Komputer Indonesia, 1-6.

Nasir, M. S. G. (2019). Tambur Peh-Cun sebagai iringan lomba perahu naga dalam upacara Peh-Cun di Tangerang Banten. Tugas Akhir Fakultas Seni Pertunjukan, Institut Seni Indonesia Yogyakarta.

Purwanto, Erwan Agus., Sulistyastuti, D. R. (2017). Metode Penelitian kualitatif untuk administrasi publik dan masalah - masalah sosial (Edisi Kedu). Penerbit Gava Media. 
Reza, M., Menjadi, P., Benteng, C., Etnis, I., Jurnal, S., Masyarakat, S., \& Zaini, M. R. (2014). Perjalanan menjadi cina benteng : studi identitas etnis di Desa Situgadung. 19(1), 93-117.

Rosyadi. (2010). Festival Peh Cun, menelusuri tradisi etnis Cina di Kota Tangerang. Patanjala, 2(1), 18-34.

Santosa, I. (2012). Peranakan Tionghoa di Indonesia- catatan perjalanan dari Barta ke Timur. PT.Kompas Media Nusantara.

Shahab, Y. Z. (2000). Alih fungsi seni dalam masyarakat kompleks : kasus liangliong dan barongsai. Jurnal Antropologi Indonesia, 6(1), 37-46.

Siregar, R. S., \& Sembada, G. G. (2019). Rancangan promosi festival Cisadane Tangerang promotional design of Cisadane Tangerang festival. EProceeding of Art \& Design, 6(2), 1741-1748.

Sulistomo, B. A. (2018). Perancangan buku ilustrasi kebudyaan peranakan Tionghoa di Tangerang. Tugas Akhir Fakultas Seni Rupa, Institut Seni Indonesia Yogyakarta.

Tracy, M. (2017). Sejarah, makna, dan tradisi Bakcang (Peh Cun). Pegipegi. https:// www.pegipegi.com/travel/sejarah-makna-dan-tradisi-haribakcang-peh-cun/

Zuliansyah, R. A. (2019). Semarak lomba perahu naga di festival Peh Cun 2019 Kota Tangerang. Tangerangnews. https://tangerangnews.com/kotatangerang/read/27372/Semarak-Lomba-Perahu-Naga-di-Festival-PehCun-2019-Kota-Tangerang 